\title{
PHYSICAL TRAINING IN ATHLETES: ANALYSIS OF CARDIAC AUTONOMIC MODULATION
}

\author{
TREINAMENTO FÍSICO EM ESPORTISTAS: ANÁLISEDA MODULAÇÃOAUTONÔMICA CARDÍACA

\section{ENTRENAMIENTO FÍSICO EN DEPORTISTAS: ANÁLISIS DE LA MODULACIÓN AUTONÓMICA CARDÍACA}

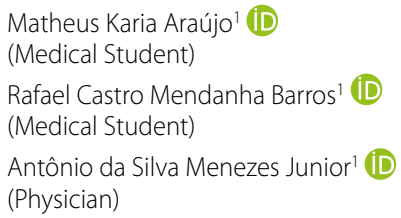

Rafael Castro Mendanha Barros' ${ }^{1}$ iD (Medical Student)

Antônio da Silva Menezes Junior ${ }^{1}$ (DD (Physician)

1. Pontifícia Universidade Católica de Goiás, Goiânia, GO, Brazil.

\section{Correspondence:}

Rafael Castro Mendanha Barros. Avenida T13, 786, Res. Millenium, apto 1402 A, Setor Bueno, Goiânia, GO. 74230-050.

rafaelmendanhab@gmail.com

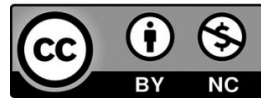

\section{ABSTRACT}

Introduction: Cardiac autonomic modulation (CAM) is a result of the balance between the sympathetic and parasympathetic systems. This interaction results in heart rate variation (HRV), analyzed by specific electrocardiographic parameters. These parameters are modified by the practice of physical activity, indicating better cardiac conditioning. Objectives: To evaluate the cardiac autonomic modulation of athletes of the XXVIII Ecological Walk at two separate times during their period of physical training. Also, to link the practice of physical activity with stress reduction in these individuals. Methods: 24-hour Holter exams were performed at two times (before and after a 2-month period of non-standard physical training), and the results were analyzed using the software programs Epi-Info 7 and BioEstat 5.0. Inferential analysis was performed by the nonparametric Shapiro-Wilk test. Statistical significance was assigned to p values less than 0.05 , with $95 \%$ confidence interval $(95 \% \mathrm{Cl})$. Results: The sample was mostly male $(n=14 ; 77.78 \%)$, with a mean age of 49.55 years. No individual trained for less than 60 days; most (47.06\%) trained for 151-200 days, with walking being the predominant modality (64.71\%). No statistically significant difference was found in the parameters HRV pNN50 ( $p=0.18), \operatorname{rMSSD}(p=0.14)$ or HF $(p=$ 0.117) after the evaluated training period. Conclusions: Participants who are longtime sportsmen and physically active showed parasympathetic saturation, therefore, they did not show significant changes in HRV. Also, low levels of stress were observed in those who practiced physical activity. Level of evidence II; Prognosis Study.

Keywords: Autonomic nervous system; Heart rate; Exercise.

\section{RESUMO}

Introdução: A modulação autonômica cardiaca (MO) é resultado do equilibrio entre os sistemas simpático e parassimpático. Essa interação resulta na variação da frequência cardíaca (VFC) analisada por parâmetros eletrocardiográficos específicos, que são modificados pela prática de atividade física, indicando melhor condicionamento cardíaco. Objetivos: Analisar a modulação autonômica cardíaca em esportistas da XXVIII Caminhada Ecológica em dois momentos durante seu período de treinamento físico. Além disso, relacionar a prática de atividade física com a redução do estresse nesses individuos. Métodos: Foram realizados exames de Holter de 24 horas em dois momentos (antes e depois de um período de dois meses de treinamento físico não padronizado), sendo os resultados analisados por meio dos programas Epi-Info 7 e BioEstat 5.0. A análise inferencial foi feita pelo teste não paramétrico de Shapiro-Wilk. A significância estatística foi atribuída aos valores de p menores que 0,05 e intervalo de confiança de 95\% (IC 95\%). Resultados: A amostra era majoritariamente masculina ( $n=14 ; 77,78 \%)$, com média de idade de 49,55 anos. Nenhum indivíduo treinou por menos de 60 dias, a maioria (47,06\%) treinou por 151 a 200 dias, sendo a caminhada a modalidade predominante (64,71\%). Não foi encontrada diferença estatisticamente significativa nos parâmetros de VFC $p N N 50(p=0,18), \operatorname{rMSSD}(p=0,14)$ e HF $(p=$ $0,117)$ depois do período de treinamento avaliado. Conclusão: Os participantes que são esportistas de longa data e fisicamente ativos apresentaram saturação parassimpática, por isso não evidenciaram alterações significativas na VFC. Além disso, observou-se menor nível de estresse nos praticantes de atividade física. Nível de evidência ll; Estudo prognóstico.

Descritores: Sistema nervoso autônomo; Frequência cardíaca; Exercício físico.

\section{RESUMEN}

Introducción: La modulación autonómica cardíaca $(\mathrm{MO})$ es el resultado del equilibrio entre los sistemas simpático y parasimpático. Esta interacción resulta en la variación de la frecuencia cardíaca (VFC), analizada por parámetros electrocardiográficos específicos, que son modificados por la práctica de actividad física, indicando mejor acondicionamiento cardíaco. Objetivos: Analizar la modulación autonómica cardíaca en deportistas de la XXVIII Caminata Ecológica en dos momentos durante su período de entrenamiento físico. Además, relacionar la práctica de actividad física con la reducción del estrés en estos individuos. Métodos: Fueron realizados exámenes Holter de 24 horas en dos momentos (antes y después de un período de dos meses de entrenamiento físico no estandarizado), siendo los resultados analizados por medio de los programas Epi-Info 7 y BioEstat 5.0. El análisis inferencial se realizó mediante el test no paramétrico de Shapiro-Wilk. La significancia estadística fue atribuida a los valores de p inferiores a 0,05 e intervalo de confianza del 95\% (IC 95\%). Resultados: La muestra era mayoritariamente masculina ( $n=14 ; 77,78 \%)$, con un promedio de edad de 49,55 años. Ningún individuo entrenó durante menos de 60 días, la mayoría (47,06\%) entrenó durante 151-200 días, siendo la caminata la modalidad predominante (64,71\%). No 
fue encontrada diferencia estadísticamente significativa en los parámetros de VFC $p N N 50(p=0,18)$, rMSSD $(p=0,14)$ y HF $(p=0,117)$ después del período de entrenamiento evaluado. Conclusión: Los participantes que son deportistas de larga data y físicamente activos presentaron saturación parasimpática, por eso no evidenciaron alteraciones significativas en la VFC. Además, se observó un menor nivel de estrés en los practicantes de actividad física. Nivel de evidencia ll; Estudio pronóstico.

Descriptores: Sistema nervioso autónomo; Frecuencia cardiaca; Ejercicio físico.

\section{INTRODUCTION}

Sport has several benefits, such as improved physical' and psychosocial health (participation in sport reduces stress, lowers rates of depression and preserves mental health). ${ }^{2}$ Moreover, due to parasympathetic modulation, athletes have improved cardiac function with higher heart rate variability (HRV).,4

HRV is the variation in the time interval between consecutive heartbeats, corresponding to the balance between the sympathetic and parasympathetic autonomic nervous systems, outlined in Figure 1.,6 This system can be analyzed by specific parameters of the 24-hour Holter monitor test. ${ }^{7.8}$ (Table 1)

The parasympathetic system lowers the heart rate, while the sympathetic system increases it. ${ }^{8}$ Hence HRV analysis is important to assess cardiovascular conditioning (fitness) in athletes, evidencing the cardiac parasympathetic tone..$^{8-10}$

Athletes have vagal modulation as the main mechanism responsible for the increase in $\mathrm{HRV}_{1}^{11-13}$ and these changes are more evident in those who participate in aerobic activities rather than anaerobic activities. ${ }^{9}$ These changes, however, do not always manifest in elite athletes, ${ }^{14}$ who exhibit parasympathetic saturation and HRV stagnation. ${ }^{11}$ Studies propose that the relationship between HRV and cardiac parasympathetic action does not vary in linear function, but in quadratic function: HRV increases with an increase in parasympathetic activity, there is saturation of parasympathetic receptors and a plateau is reached. From this point on, HRV may decrease, even in the presence of vagal stimuli. ${ }^{15-17}$ This raises the question as to whether the same phenomenon occurs in individuals who have been engaging in physical activity for a long period of time, even though they are not elite athletes. The sample group of this study fits the above profile.

Accordingly, the aim of the study was to assess the cardiac autonomic modulation (CAM) of athletes participating in the XXVIII Ecological Walk during the pre-competition training period through HRV, carrying out

Table 1. Variables of the heart rate variability assessment.

\begin{tabular}{|c|c|c|}
\hline Parameter & Unit & Description \\
\hline & & Time domain \\
\hline SDNN & $\mathrm{ms}$ & Standard deviation of all NN intervals \\
\hline SDANN & $\mathrm{ms}$ & $\begin{array}{l}\text { Standard deviation of the average NN intervals } \\
\text { for each 5-minute segment of a recording }\end{array}$ \\
\hline RMSSD & $\mathrm{ms}$ & $\begin{array}{l}\text { Root mean square of successive } \\
\text { RR interval differences }\end{array}$ \\
\hline SDNN Index & ms & $\begin{array}{l}\text { Mean of the standard deviation } \\
\text { of the mean NN intervals for each } \\
5 \text {-minute segment of a recording }\end{array}$ \\
\hline NN50 Count & & $\begin{array}{c}\text { Number of pairs of adjacent NN intervals } \\
\text { differing by more than } 50 \mathrm{~ms} \text { in the recording }\end{array}$ \\
\hline \multirow[t]{2}{*}{ pNN50 } & $\%$ & $\begin{array}{l}\text { NN50 count divided by the } \\
\text { number of NN intervals }\end{array}$ \\
\hline & & Frequency domain \\
\hline VLF (Very Low Frequency) & $\mathrm{Hz}$ & Power contained in the range below $0.04 \mathrm{~Hz}$ \\
\hline LF (Low Frequency) & $\mathrm{Hz}$ & $\begin{array}{l}\text { Power contained in the range } \\
\text { from } 0.04 \text { to } 0.15 \mathrm{~Hz}\end{array}$ \\
\hline HF (High Frequency) & $\mathrm{Hz}$ & Power contained in the range from 0.15 to 0.4 \\
\hline $\mathrm{LF} / \mathrm{HF}$ & & Ratio of LF-to-HF power \\
\hline
\end{tabular}

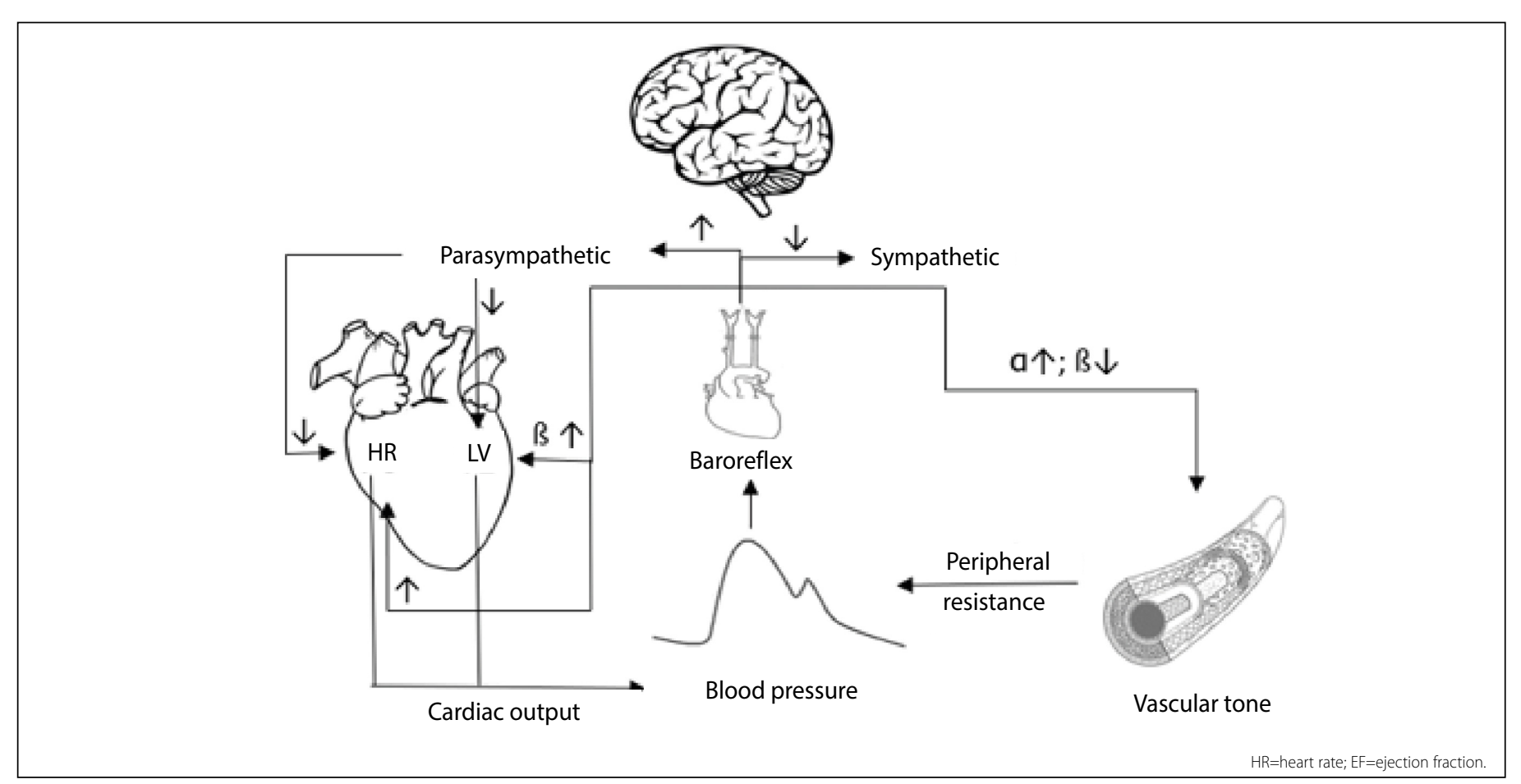

Figure 1. Mechanisms of control of heart rate and blood pressure. Sympathetic and parasympathetic actions can be assessed by heart rate variability. 
Holter monitor tests before and after physical preparation for the event. We assessed whether non-standardized physical training, performed independently by the athletes, was able to cause significant changes in HRV values and in scores on the Perceived Stress Scale (PSS) questionnaire.

\section{MATERIALS AND METHODS}

This is a prospective observational, descriptive, analytical and longitudinal study.

The Ecological Walk, which takes place over a distance of $310 \mathrm{~km}$ in the state of Goiás with athletes covering $60 \mathrm{~km}$ per day, is a highlight in the regional context of this study. The athletes participating in this event are the subjects of this research project.

To obtain the sample, the investigators contacted the 29 athletes from the previous edition of the event and included all athletes interested in the study who passed the physical screening test, performed only by candidates with medical evidence of physical fitness and absence of major comorbidities. Individuals who did not undertake the screening test or participate in the two stages of the Holter monitor test, and individuals who did not wish to participate in the study were excluded.

The 24-hour Holter monitor tests, carried out at two different time points (April and June 2019, totaling two months of training), were performed using Holter DMS Brasil ${ }^{\circledR}$ monitors (São Paulo-SP, Brazil) and analyzed with CardioScan 12 DMS $^{\circledR}$ (Stateline, NV, USA). PSS, ${ }^{18}$ sociodemographic and physical activity characterization (PAC) questionnaires were applied. The PSS questionnaire has 14 questions, which address how the patient has dealt with life's problems and how he/she has felt emotionally when faced with difficulties imposed on him/her. The higher the score, the greater the perception of stress. ${ }^{18}$

The data were tabulated in Microsoft Exce ${ }^{\circledR}$ (Redmond, WA, USA) and analyzed using Epi Info $7{ }^{\circledR}$ (Washington DC, USA) and Bioestat 5.0 ${ }^{\circledR}$ (Tefé-AM, Brazil). Categorical variables were assessed by absolute and relative frequencies. In the inferential analysis, variables were subjected to the Shapiro-Wilk test to assess their normality. Parameters with non-normal distribution were subjected to the nonparametric Mann-Whitney test, while parameters with normal distribution were subjected to Student's T test. Fisher's exact test was used to associate categorical variables. Statistical significance was attributed to $p$-values of $<0.05$ and a 95\% confidence interval (95\% Cl).

The participants signed the Informed Consent Form (ICF) and the study was approved by the Institutional Review Board of Pontifícia Universidade Católica de Goiás (CAAE 06671919.1.0000.0037) once all the necessary requirements had been met.

\section{RESULTS}

\section{Study adherence in the sample}

Of the initial sample of 29 subjects, 18 met the inclusion criteria. Of these, only 1 failed to complete the study in full, as they did not answer the PAC questionnaire. Therefore, the subject was included for all other analyses, except for the PAC. The remaining 17 subjects completed the study in full, totaling 18 participants in the final sample.

\section{Characterization of the sample}

The sample consisted of $77.78 \%$ men $(n=14)$ and $22.22 \%$ women $(n=4)$, with a mean age of 49.55 years $(S D=10.55)$, median of 51 years, minimum age of 32 years and a maximum age of 68 years.

\section{Characterization of the physical activity of the athletes}

The PAC of the athletes (Tables 2, 3 and 4) qualifies the training of the sample for the Ecological Walk. The majority (58.82\%) prepared for a minimum period of 151 days, 100\% of the sample trained for at least
60 days, and $76.47 \%$ of the participants trained at least four times a week. Most training sessions had a minimum duration of two hours (76.47\%), and $94.74 \%$ of the sample had been participating in regular physical activity for at least three years. Thus, it is concluded that the average intensity of the athletes' physical preparation for the event was 350 hours (standard deviation 200.96 hours), considered moderate intensity preparation.

We should emphasize that there was no standardization of physical training for the participants, thus each athlete followed his or her own pattern of training frequency, duration and intensity, described in Tables 2 to 4.

\section{Effect of the physical preparation of the sample on the pa- rameters of the 24-hour Holter monitor test}

The 24-hour Holter monitor test parameters are specified in Tables 5 and 6. The variables mean heart rate (mean HR), pNN50, rMSSD, High Frequency (HF) power, Low Frequency (LF), and parasympathetic and sympathetic stimulation percentage of the athletes did not exhibit normal

Table 2. Characterization of the Physical Activity of the athletes (I).

\begin{tabular}{c|c|c}
\hline & $\mathbf{n}$ & $\%$ \\
\hline Length of training for the event & & \\
\hline 51 to 100 days & 2 & 11.77 \\
\hline 101 to 150 days & 5 & 29.41 \\
\hline 151 to 200 days & 8 & 47.06 \\
\hline 201 to 250 days & 0 & $0 \%$ \\
\hline 251 to 300 days & 1 & 5.88 \\
\hline 301 to 350 days & 1 & 5.88 \\
\hline Duration of each training session & & \\
\hline 1 to 2 hours & 4 & 23.53 \\
\hline 2 to 3 hours & 7 & 41.18 \\
\hline 3 to 4 hours & 5 & 29.41 \\
\hline 4 to 5 hours & 1 & 5.88 \\
\hline
\end{tabular}

Table 3. Characterization of the Physical Activity of the athletes (II).

\begin{tabular}{c|c|c}
\hline & $\mathbf{n}$ & $\%$ \\
\hline Weekly training frequency & & \\
\hline twice & 2 & 11.76 \\
\hline 3 times & 2 & 11.76 \\
\hline 4 times & 7 & 41.18 \\
\hline 5 times & 1 & 5.88 \\
\hline 6 times & 3 & 17.65 \\
\hline 7 times & 1 & 5.88 \\
\hline$>7$ times & 1 & 5.88 \\
\hline Mode of training & & \\
\hline Running & 5 & 29.41 \\
\hline Jogging & 1 & 5.88 \\
\hline Walking & 11 & 64.71 \\
\hline
\end{tabular}

Table 4. Characterization of the Physical Activity of the athletes (III).

\begin{tabular}{c|c|c}
\hline & $\mathbf{n}$ & $\%$ \\
\hline Went without training & & \\
\hline No & 7 & 41.18 \\
\hline$<7$ days & 3 & 17.65 \\
\hline $7-14$ days & 3 & 17.65 \\
\hline $14-21$ days & 2 & 11.76 \\
\hline$>22$ days & 2 & 11.76 \\
\hline How long have they participated & & \\
in regular physical activity & 1 & 5.88 \\
\hline Less than 3 years & 2 & 11.76 \\
\hline Between 3 and 5 years & 2 & 11.76 \\
\hline Between 5 and 8 years & 12 & 70.59 \\
\hline More than 8 years & & \\
\hline
\end{tabular}


Table 5. Effect of physical preparation on the 24-hour Holter parameters (I).

\begin{tabular}{|c|c|c|c|c|}
\hline & Median & Mean & $\begin{array}{l}\text { Standard } \\
\text { Deviation }\end{array}$ & p-value \\
\hline \multicolumn{5}{|l|}{ Mean HR } \\
\hline Holter 1 & 63 bpm & $63.33 \mathrm{bpm}$ & 9.62 bpm & \multirow{2}{*}{0.936} \\
\hline Holter 2 & 62 bpm & $68.22 \mathrm{bpm}$ & 28.78 bpm & \\
\hline \multicolumn{5}{|l|}{ pNN50 } \\
\hline Holter 1 & 10,5 & 12,16 & 9.19 & \multirow{2}{*}{0.178} \\
\hline Holter 2 & 15,5 & 16,83 & 11.14 & \\
\hline \multicolumn{5}{|l|}{ rMSSD } \\
\hline Holter 1 & $33 \mathrm{~ms}$ & $34.77 \mathrm{~ms}$ & $9.92 \mathrm{~ms}$ & \multirow{2}{*}{0.14} \\
\hline Holter 2 & $38.5 \mathrm{~ms}$ & $41.22 \mathrm{~ms}$ & $13.94 \mathrm{~ms}$ & \\
\hline \multicolumn{5}{|c|}{ High Frequency (HF) } \\
\hline Holter 1 & $219.9 \mathrm{~ms} 2$ & $229.53 \mathrm{~ms} 2$ & $134.81 \mathrm{~ms} 2$ & \multirow{2}{*}{0.117} \\
\hline Holter 2 & $296.45 \mathrm{~ms} 2$ & $321.56 \mathrm{~ms} 2$ & $218.37 \mathrm{~ms} 2$ & \\
\hline
\end{tabular}

Table 6. Effect of physical preparation on the 24-hour Holter parameters (II).

\begin{tabular}{|c|c|c|c|c|}
\hline & Median & Mean & $\begin{array}{l}\text { Standard } \\
\text { Deviation }\end{array}$ & p-value \\
\hline \multicolumn{5}{|c|}{ Low Frequency (LF) } \\
\hline Holter 1 & $822.4 \mathrm{~ms} 2$ & $916.99 \mathrm{~ms} 2$ & $475.66 \mathrm{~ms} 2$ & \multirow{2}{*}{0.601} \\
\hline Holter 2 & $926.6 \mathrm{~ms} 2$ & $986.44 \mathrm{~ms} 2$ & $501.82 \mathrm{~ms} 2$ & \\
\hline \multicolumn{5}{|c|}{ Parasympathetic } \\
\hline Holter 1 & $95.50 \%$ & $95.15 \%$ & $1.62 \%$ & \multirow{2}{*}{0.093} \\
\hline Holter 2 & $94.50 \%$ & $93.33 \%$ & $3.54 \%$ & \\
\hline \multicolumn{5}{|c|}{ Sympathetic } \\
\hline Holter 1 & $4.50 \%$ & $4.84 \%$ & $1.69 \%$ & \multirow{2}{*}{0.093} \\
\hline Holter 2 & $5.50 \%$ & $6.66 \%$ & $3.54 \%$ & \\
\hline
\end{tabular}

distribution after undergoing the Shapiro-Wilk test, so were evaluated using the Mann-Whitney test. There was no statistical difference between the mean HRs ( $p=0.94)$, the values of pNN50 ( $p=0.18), \operatorname{rMSSD}(p=0.14)$, $\mathrm{HF}(\mathrm{p}=0.12)$ and $\mathrm{LF}(\mathrm{p}=0.6)$, the percentage of parasympathetic stimulation $(p=0.09)$ and the percentage of sympathetic stimulation $(p=0.09)$.

Figures 2-4 compare the periods before and after the physical preparation of athletes on an individual basis, evidencing both a subject with specific changes in HRV (Figures 2 and 3 ) and a subject without any changes (Figure 4). Figures 2 and 3 show that, despite the absence of statistical significance before and after the physical training sessions of the sample, one athlete showed improvement.

Figures 2 and 3, referring to the same participant, indicate, specifically, the expected change in HRV after a period of physical training. Both reveal an increase in HRV parameters identified by the Holter monitor test. This athlete, in particular, started their physical training just 24 days before the first Holter monitor test, having previously been sedentary. The increase in HRV can be attributed to the fact that the athlete, after an inactive period, underwent walking training sessions six times a week, for one to two hours, totaling an intensity of 84 hours of preparation for the event.

\section{Perceived Stress Scale Questionnaire}

The average score obtained by the participants was 18.36 $(S D=8.92)$, while the median was 20 points and the minimum and maximum scores 4 and 35, respectively. Athletes aged between 31 and 40 years achieved the highest average score (23 points), while athletes over 51 years old had the lowest stress rate (average of 15.55 points).

Dividing the sample into two groups ( $>50$ years and $<50$ years) the average score in the older group was 15.55 (SD 9.19), while the average score in the younger group was 22.33 (SD 7.39). This variable (with normal distribution) was evaluated using Student's T test (equal variance, F-statistic $<4$ ). Despite the difference between means, there

\section{Spectral analysis}

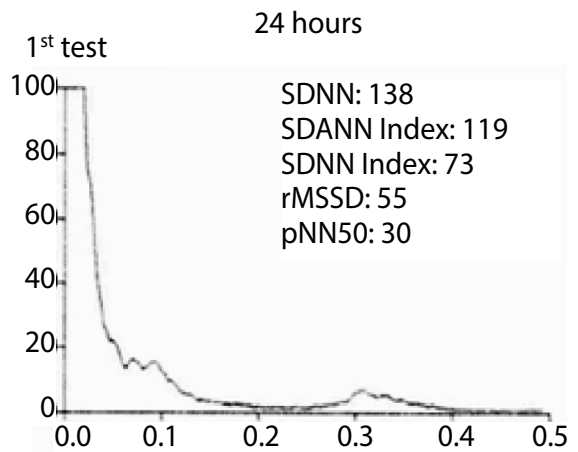

Anal.: 5313.8; VLF: 3981.7; LF: 834.5; HF: 447.9

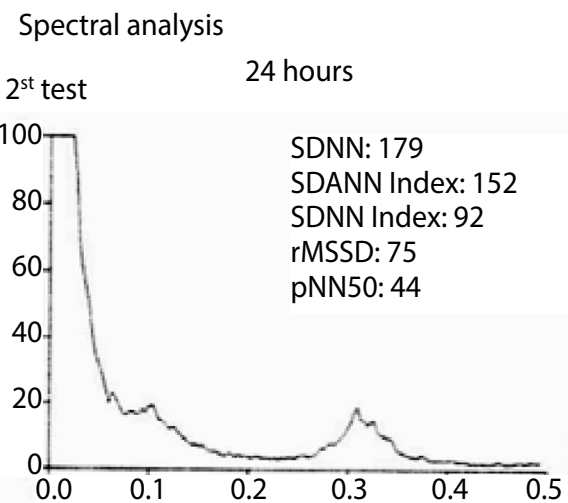

Anal.: 7725.6; VLF: 5397.1; LF: 1227.6; HF: 965.3

Figure 2. Comparison of individual Holter monitoring in the spectral analysis (No.2). A greater than 2-fold increase was observed specifically in the High Frequency power along with an increase in the parameters related to heart rate variability.

was no statistical significance between them $(p=0.104)$. To assess the relationship between the difference in means and physical training intensity, we compared training intensity in these groups ( $>50$ years and $<50$ years). The mean training intensity of athletes aged $>50$ years was 374 hours (SD 198.36), while that of athletes $<50$ years was 323 hours (SD 213.93). The variable also obtained normal distribution and Student's $T$ test revealed a $p=0.617$ (equal variance, F-statistic $<4$ ), with no statistical difference between means.

\section{DISCUSSION}

Participation in physical activity did not significantly change the average HRV of the participants of this study before and after the period of physical preparation for the event. Several other studies are consistent with the results found in this research project. A Uruguayan study compared a group of sedentary people (16 people aged 39-82 years and 9 people aged 15-20 years) with a group of physically active people (9 young people aged 15-20 years) who performed aerobic activities five times a week. The electrocardiographic recordings did not show a statistically significant difference between HRV values in the sedentary group and the physically active group. ${ }^{19}$ Similarly, a study by the University of Colorado assessed the impact of aerobic activity on 8 sedentary women aged 50-60 years. For 12 weeks, the women were instructed to undertake walking sessions on their own initiative 3-4 days a week, with durations of at least 30-45 minutes a day. It was discovered that neither time nor frequency domain parameters showed any statistically significant changes when comparing values before and after 12 weeks 


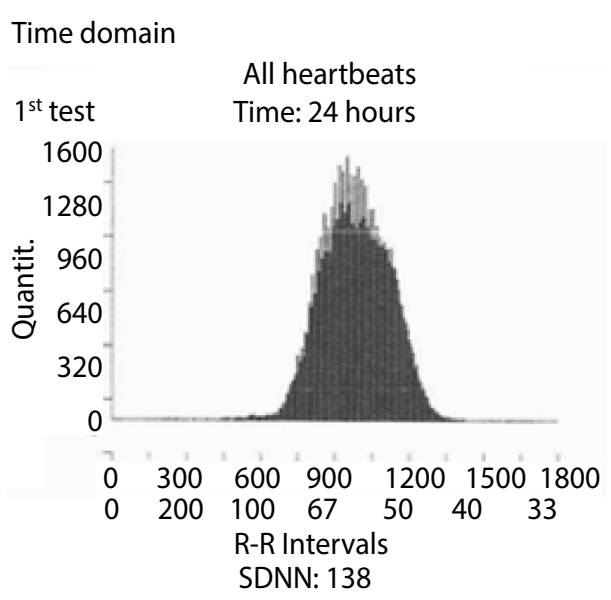

Time domain

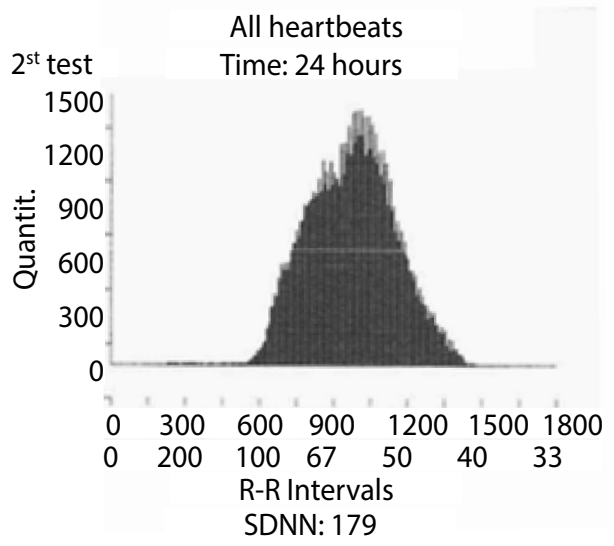

Figure 3. Histogram comparing pre and post-physical exercise with changes. The histogram is broader at the base, indicating greater heart rate variability (greater difference between RR-intervals over the course of the recording) and displacement of the graph to higher RR-interval values (reduction of average heart rate).

of training. ${ }^{20}$ Both studies showed similarities between their samples and the mode of physical training in comparison to this study. Another study assessed test $(n=19)$ and control $(n=15)$ groups, with a mean age of 46 years, before and after 24 moderate-intensity training sessions, finding no statistically significant changes in HRV. ${ }^{21}$

Studies have shown that HRV is inversely related to age. A Japanese prospective cohort with 15 people who did not undergo a training program (initial mean age of 70 years and final age of 85 years) performed two tests with a 15-year interval between them. This research project concluded that HRV parameters decrease with increasing age. ${ }^{22}$ An Asian study assessed 180 subjects aged 15-60 years, divided into three groups (15-30 years; $31-45$ years and $46-60$ years). The investigators concluded that there is an inverse correlation between increasing age and HRV parameters. ${ }^{23}$ Another prospective cohort study assessed the impact of physical activity on cardiac physiology in more than 4000 subjects, over 10 years. There was a reduction in HRV parameters due to the sample aging process. ${ }^{24}$

Several studies, however, have shown results different from those presented by this study. It is possible to relate participation in physical activities with increased HRV based on the available literature. A North American research project found that moderate- to high-intensity aerobic exercises had positive effects on pNN50, rMSSD and HF power, but only 12 weeks into the training program. ${ }^{25}$ Another study also revealed that a minimum of 30 weeks of moderate exercise is needed to increase parameters that indicate improvement in $\mathrm{HRV}^{26} \mathrm{~A}$ study that assessed
Time domain

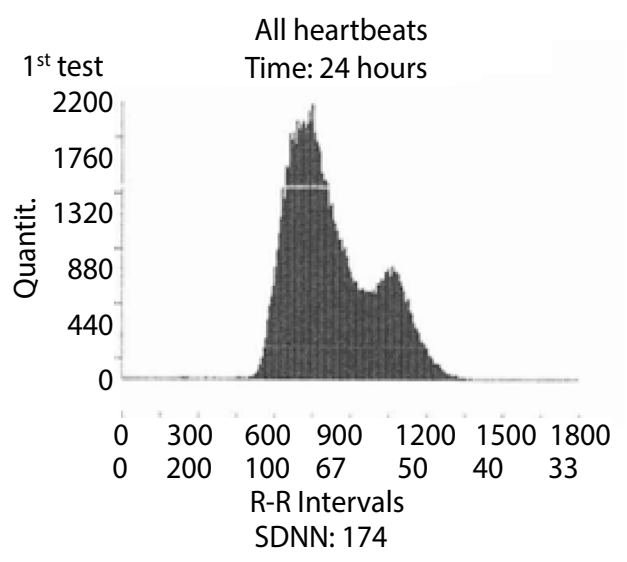

Time domain

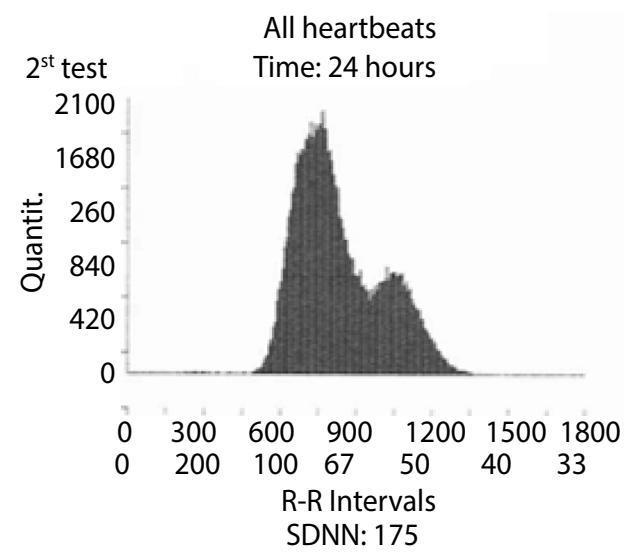

Figure 4. Histogram comparing pre and post-physical exercise with changes. Two peaks can be seen in the histogram: one at around $1000 \mathrm{~ms}$, corresponding to the nighttime heart rate, and the other at around $750 \mathrm{~ms}$, relating to the daytime heart rate. Note that there were no changes in the general shape of the histogram before and after physical preparation, which can be attributed to the fact that the athlete had already been engaging in regular physical activity for more than 9 years, having trained for the event in the walking category only twice a week in 3-4 hour sessions. It is assumed that the lack of changes in HRV is due to a possible parasympathetic saturation and tolerance to long-term physical exercise.

28 athletes ( 17 runners, 4 cyclists, 4 basketball players, 2 swimmers and 1 rower), training 8 hours a week, and 28 sedentary subjects, indicated a significant difference in HRV parameters, which were higher in the athletes than in the sedentary subjects. ${ }^{27}$ Although these data differed from the means and statistical evaluation of this study, they reflect the findings specifically found in the athlete from this study who had increased CAM values.

Most of the studies that showed statistically significant results relating physical activity and increased HRV worked with samples and methodologies with the following essential characteristics: either the subjects were previously sedentary and were exposed to physical activity, after which they were assessed in terms of HRV, or the sample was divided into a case group (physically active subjects) and a control group (sedentary subjects), after which HRV was compared between the two groups in the post-training period. Comparing this literature with this study, it can be seen that the sample and methodology of this research project had different characteristics from those reported in studies that find statistical significance in the relationship between physical activity and increased HRV. Many of the participants in this study (94.74\%) were already longtime athletes, and had been engaging in regular physical activity for at least three years. Therefore, it is assumed that the physical exercise performed 
by the subjects was sufficient to maintain their pre-existing physiological conditions. It is believed that the participants already had parasympathetic cardiac saturation prior to the start of the study. In this adaptive process, the parasympathetic action is able to increase HRV until it reaches a plateau, from which point on there are no more relevant changes in electrocardiographic parameters. ${ }^{11,16}$ Accordingly, studies suggest that, for these subjects, the quantification of cardiac parasympathetic action using Holter parameters may be biased, as parasympathetic saturation alters the true cardiac vagal action. ${ }^{16,28}$ Due to the quadratic function that represents the relationship between HRV and parasympathetic action, we can infer that the study participants are in the plateau phase, in which, despite vague stimuli, there are no significant changes in HRV. ${ }^{16}$

The findings of this study in relation to self-perceived stress in athletes indicated that the participants had low levels of stress on the PSS questionnaire. The average score obtained was 18.36 points, whereas the maximum score on the questionnaire is 56 points. These findings corroborate the literature, which already confirmed lower rates of stress in physically active subjects. One study, using the PSS, revealed that physical active subjects exhibited a lower level of stress than physically inactive subjects. ${ }^{29} \mathrm{~A}$ Canadian study indicated that adults with a high level of stress benefited from physical activity, showing a reduction in stress rates. ${ }^{30}$

\section{Limitations}

This study has limitations, such as the small sample size $(n=18)$, thereby reducing the statistical power of the analysis. In addition, the non-significance of HRV in the participants can be related to the fact that the majority of the sample (50\%) is over 50 years old, which may negatively influence the parameters studied, as increasing age is related to the decrease in HRV. ${ }^{24-26}$ Another factor is the non-standardization of the participants' physical activity (no standardized physical training program was established to equalize the physical preparation of all athletes), carried out on an individual arbitrary basis, which may have affected the statistical significance of the HRV results. It should be noted that most of the participants (94.74\%) had already been exercising for at least three years prior to the application of the first Holter monitor test. Therefore, it is believed that the exercises undertaken were sufficient to maintain their physiological conditions of pre-existing parasympathetic saturation (HRV increased and sustained on a plateau), ${ }^{11,16,28}$ which suggest excellent cardiac health status. ${ }^{8-10}$

It is recommended that further studies be carried out on athletes to clarify the influence of physical activity on parasympathetic saturation. Research studies with a larger sample, standardization of physical activity, longer training period and serial electrocardiographic recordings are suggested to better monitor changes in HRV.

\section{CONCLUSIONS}

This study concluded that longtime, physically active athletes have parasympathetic cardiac saturation. Thus, the physical training undertaken by the participants during the research was sufficient to maintain their pre-existing CAM status, justifying the absence of significant changes in HRV. Furthermore, the average score obtained on the PSS questionnaire was not high, demonstrating a lower level of stress in the athletes studied, especially in the older subjects.

$\overline{\text { All authors declare no potential conflict of interest related to this article }}$

AUTHORS' CONTRIBUTIONS: Each author made significant individual contributions to this manuscript. MKA: writing, revision, application of questionnaires, application of tests, statistical analysis, data analysis, elaboration of the research project; RCMB: writing, revision, data analysis, application of questionnaires, application of tests, statistical analysis, contact with the study sample, elaboration of the research project; ASMJ: intellectual concept, idealization of the research project, revision, guidance, providing devices to perform the tests.

\section{REFERENCES}

1. Oja P, Titze S, Kokko S, Kujala UM, Heinonen A, Kelly P, et al. Health benefits of different sport disciplines for adults: Systematic review of observational and intervention studies with meta-analysis. Br J Sports Med. 2015;49(7):434-40.

2. Eime RM, Young JA, Harvey JT, Charity MJ, Payne WR. A systematic review of the psychological and social benefits of participation in sport for adults : informing development of a conceptual model of health through sport. Int J Behav Nutr Phys Act. 2013;10:135

3. Abad CCC, do Nascimento AM, Gil S, Kobal R, Loturco I, Nakamura FY, et al. Cardiac Autonomic Control in High Level Brazilian Power and Endurance Track-and-Field Athletes. Int J Sports Med. 2014;35(09):772-8.

4. Turmel J, Bougault $V$, Boulet $L P$, Poirier $P$. Exaggerated blood pressure response to exercise in athletes. Blood Press Monit. 2012;17(5):184-92.

5. Oliveira ALMB, Rohan PA, Gonçalves TR, Soares PPS. Effects of Hypoxia on Heart Rate Variability in Healthy Individuals: A Systematic Review. Int J Cardiovasc Sci. 2017;30(3):251-61.

6. Shaffer F, Ginsberg JP. An Overview of Heart Rate Variability Metrics and Norms. Front Public Health. 2017;5:258.

7. Singh N, Moneghetti KJ, Christle JW, Hadley D, Froelicher V, Plews D. Heart rate variability: An old metric with new meaning in the era of using $\mathrm{mHealth}$ technologies for health and exercise training guidance. Part two: Prognosis and training. Arrhythm Electrophysiol Rev. 2018;7(4):247-55.

8. Avezum Junior Á, Feldman A, Carvalho ACDC, Sousa ACS, Mansur ADP, Bozza AEZ, et al. V Diretriz da Sociedade Brasileira de Cardiologia sobre Tratamento do Infarto Agudo do Miocárdio com Supradesnível do Segmento ST. Arq Bras Cardiol. 2015;105(2):1-105.

9. Mazon J, Gastaldi A, Sacco TD, Cozza I, Dutra S, Souza H. Effects of training periodization on cardiac autonomic modulation and endogenous stress markers in volleyball players. Scand J Med Sci Sports. 2013;23(1):114-20.

10. Shen MJ, Zipes DP. Role of the autonomic nervous system in modulating cardiac arrhythmias. Circ Res. 2014;114(6):1004-21.

11. Plews DJ, Laursen PB, Buchheit M. Day-to-Day Heart-Rate Variability Recordings in World-Champion Rowers: Appreciating Unique Athlete Characteristics. Int J Sports Physiol Perform. 2017;12(5):697-703.

12. Azevedo LF, Perlingeiro PS, Hachul DT, Gomes-Santos IL, Brum PC, Allison TG, et al. Sport Modality Affects Bradycardia Level and Its Mechanisms of Control in Professional Athletes. Int J Sports Med. 2014;35(11):954-9.

13. Flatt AA, Esco MR. Heart rate variability stabilization in athletes: towards more convenient data acquisition. Clin Physiol Funct Imaging. 2016;36(5):331-6.

14. Plews DJ, Laursen PB, Stanley J, Kilding AE, Buchheit M. Training adaptation and heart rate variability in elite endurance athletes: Opening the door to effective monitoring. 2013;43(9):773-81.

15. Malik M, Camm AJ. Components of heart rate variability - what they really mean and what we really measure. Am J Cardiol. 1993;72(11):821-2.
16. Goldberger JJ, Challapalli S, Tung R, Parker MA, Kadish AH. Relationship of heart rate variability to parasympathetic effect. Circulation. 2001;103(15):1977-83.

17. Berntson GG, Bigger JT, Eckberg DL, Grossman P, Kaufmann PG, Malik M, et al. Heart rate variability: Origins, methods, and interpretive caveats. Psychophysiology. 1997;34(6):623-48.

18. Luft CDB, Sanches SO, Mazo GZ, Andrade A. Versão brasileira da Escala de Estresse Percebido : tradução e validação para idosos. Rev Saúde Pública. 2007;41(4):606-15.

19. Migliaro ER, Contreras P, Bech S, Etxagibel A, Castro M, Ricca R, et al. Relative influence of age, resting heart rate and sedentary life style in short-term analysis of heart rate variability. Braz J Med Biol Res. 2001;34(4):493-500

20. Davy KP, Willis WL, Seals DR. Influence of exercise training on heart rate variability in post-menopausal women with elevated arterial blood pressure. Clin Physiol. 1997;17(1):31-40.

21. Boutcher SH, Stein P. Association between heart rate variability and training response in sedentary middle-aged men. Eur J Appl Physiol Occup Physiol. 1995;70(1):75-80.

22. Tasaki H, Serita T, Irita A, Hano O, lliev I, Ueyama C, et al. A 15-year longitudinal follow-up study of heart rate and heart rate variability in healthy elderly persons. Journals Gerontol - Ser A Biol Sci Med Sci. 2000;55(12):744-9.

23. Akhter QF, Akhter QS, Rohman F, Sinha S, Ferdousi S. Effect of Aging on Short Term Heart Rate Variability. J Bangladesh Soc Physiol. 2015;9(2):78-82.

24. Jandackova VK, Scholes S, Britton A, Steptoe A. Are changes in heart rate variability in middle-aged and older people normative or caused by pathological conditions? Findings from a large population-based longitudinal cohort study. J Am Heart Assoc. 2016;5(2):e002365.

25. Melanson EL, Freedson PS. The effect of endurance training on resting heart rate variability in sedentary adult males. Eur J Appl Physiol. 2001;85(5):442-9.

26. Seals DR, Chase PB. Influence of physical training on heart rate variability and baroreflex circulatory control. J Appl Physiol (1985). 1989;66(4):1886-95.

27. Aubert AE, Ramaekers D, Cuche Y, Lysens R, Ector H, Van De Werf F. Effect of long term physical training on heart rate variability. Comput Cardiol. 1996:17-20.

28. Kiviniemi AM, Hautala AJ, Seppänen T, Mäkikallio TH, Huikuri HV, Tulppo MP. Saturation of high-frequency oscillations of R-R intervals in healthy subjects and patients after acute myocardial infarction during ambulatory conditions. Am J Physiol Hear Circ Physiol. 2004;287(5):H1921-7.

29. Nascimento Junior JRA, Capelari JB, Vieira LF. Impacto da prática de atividade física no estresse percebido e na satisfação de vida de idosos. Rev Educ Fis. 2012;23(4):647-54.

30. Rueggeberg R, Wrosch C, Miller GE. The different roles of perceived stress in the association between older adults' physical activity and physical health. Heal Psychol. 2012;31(2):164-71. 